\title{
PENERAPAN KONSEP FINITE STATE AUTOMATA PADA DESAIN VENDING MACHINE ANGKRINGAN
}

\author{
Dedik Erwanto $^{1}$, Windu Gata ${ }^{2}$, Laela Kurniawati ${ }^{3}$, Frieyadie $^{4}$, Achmad Bayhaqy ${ }^{5}$ \\ 1,2,3,4,5Prodi Ilmu Komputer Universitas Nusa Mandiri \\ Jl. Kramat Raya No.18, RT.5/RW.7, Kwitang, Kec. Senen, Kota Jakarta Pusat, Daerah Khusus \\ Ibukota Jakarta 10450 \\ Email : 14210198@nusamandiri.ac.id ${ }^{1}$,windu@nusamandiri.ac.id², laela@nusamandiri.ac.id ${ }^{3}$, \\ frieyadie@ nusamandiri.ac.id ${ }^{4}$, achmad.acq@ nusamandiri.ac.id ${ }^{5}$
}

\begin{abstract}
Angkringan is one of the culinary arts originating from the Klaten, Surakarta and Yogyakarta regions. It has now grown to various regions in Indonesia. Typical menus that are sold at the angkringan are cat rice and ginger wedang. The location for selling angkringan is usually on the sidewalks of urban roads, villages and tourist attractions using traditional carts. The current market share of angkringan is still limited and can be increased by using a more modern method, namely vending machines. This study aims to apply the concept of finite state automata to the design of angkringan vending machines that are useful for increasing the market share of angkringan with advantages in the form of automation, practicality with a better level of cleanliness. The vending machine angkringan design will use the finite state automata method to deepen knowledge of the most basic computational models. This study has presented the application of the finite state automata concept to the design of angkringan vending machines that can produce 15 typical angkringan food and beverage products with a choice of payment methods in the form of cash and electronic money.
\end{abstract}

Keywords - FSA, angkringan, vending machine

\begin{abstract}
ABSTRAK
Angkringan adalah salah satu kuliner yang berasal dari wilayah Klaten, Surakarta dan Yogyakarta saat ini telah berkembang ke berbagai daerah di Indonesia. Menu khas yang dijual diangkringan adalah nasi kucing dan wedang jahe. Lokasi berjualan angkringan biasanya berada di trotoar jalan perkotaan, perkampungan dan tempat wisata dengan menggunakan gerobak tradisional. Pangsa pasar angkringan saat ini masih terbatas dan dapat ditingkatkan dengan menggunakan cara yang lebih modern yaitu dengan vending machine. Penelitian ini bertujuan untuk menerapkan konsep finite state automata pada desain vending machine angkringan yang bermanfaat untuk meningkatkan pangsa pasar angkringan dengan keunggulan berupa otomatisasi, praktis dengan tingkat kebersihan yang lebih baik. Desain vending machine angkringan akan menggunakan metode finite state automata untuk memperdalam pengetahuan model komputasi yang paling mendasar. Penelitian ini telah menyajikan penerapan konsep finite state automata pada desain vending machine angkringan yang dapat menghasilkan 15 produk makanan dan minuman khas angkringan dengan pilihan metode pembayaran berupa uang tunai dan uang elektronik.
\end{abstract}

Kata Kunci-FSA, angkringan, vending machine 


\section{Pendahuluan}

Angkringan merupakan salah satu kuliner yang berasal dari wilayah Klaten, Surakarta dan Yogyakarta. Masyarakat di Jawa sangat mengenal kuliner angkringan karena sudah ada sejak tahun 1950-an di Kota Yogyakarta yang awalnya dijual oleh Mbah Pairo, pedagang yang berasal dari Klaten [1]. Pedagang angkringan sebelumnya menjual daganganya dengan cara dipikul keliling, kemudian saat ini sudah menyesuaikan perkembangan zaman dengan memakai gerobak dari kayu dengan model yang ikonik dan tenda untuk atapnya yang dapat dibongkar pasang. Hal ini menunjukan bahwa ada perubahan dan penyesuaian cara berjualan angkringan dari waktu ke waktu. Menu khas warung angkringan adalah nasi kucing atau sego kucing dan wedang jahe dengan pilihan menu lain biasanya minuman teh, kopi, susu dan lauk pauk seperti sate usus, sate telur, gorengan. Nasi kucing adalah nasi yang dibungkus menggunakan daun pisang dengan porsi kecil yang dilengkapi sambal dan ikan teri sehingga disebut nasi kucing karena seperti makanan untuk hewan kucing. Kemudian untuk menu minuman khas wedang jahe, menggunakan jahe merah yang bermanfaat untuk mencegah dan mengobati berbagai penyakit, seperti: rematik, mual-mual, batuk, pegal-pegal, kepala pusing, sakit saat menstruasi, nyeri lambung, asma, nyeri otot, impoten, kanker, diabetes, penyakit jantung, bronchitis, osteoarthritis, flu, demam, gangguan pencernaan [2].

Pada awalnya warung angkringan akrab dengan orang kecil karena harga yang murah, namun saat ini usaha tersebut mulai berkembang dan disukai berbagai kalangan termasuk mahasiswa, pekerja kantoran bahkan wisatawan lokal dan mancanegara. Angkringan di Kota Yogyakarta dan Surakarta biasanya terdapat di lokasi seperti perkampungan, trotoar, pasar tradisional dan tempat wisata sedangkan di kota-kota lain saat ini juga mulai berkembang dan menjadikan angkringan sebagai usaha dengan prospek yang bagus. Di Jakarta misalnya, saat ini sudah mulai banyak warung angkringan dengan konsep yang sama seperti di kota Yogyakarta dengan area penjualan yang masih terbatas sehingga target pasarnya juga belum bisa diperluas. Keinginan masyarakat untuk membuka usaha angkringan yang semakin tinggi menyebabkan banyak bermunculan angkringan baru yang mencoba peruntungan pada usaha tersebut [3]. Jika angkringan dikemas dengan lebih modern dan dapat dijual di mall, bandara dan area publik lainnya maka akan memperluas segmen pasar dan menjangkau semua kalangan. 
Keputusan konsumen warung angkringan dipengaruhi oleh lokasi, fasilitas dan kualitas pelayanan [4]. Lokasi yang strategis, fasilitas yang mendukung dan kualitas pelayanan yang baik menjadi pertimbangan utama konsumen. Lokasi, fasilitas dan pelayanan dapat didukung dengan teknologi yang sudah berkembang saat ini. Kebutuhan konsumen terhadap layanan yang praktis dan cepat menuntut adaptasi dari pengusaha, termasuk pengusaha angkringan. Salah satu teknologi yang bisa digunakan adalah vending machine karena dapat menjangkau lokasi yang strategis, dengan fasilitas yang sudah menerapkan otomatisasi dan layanan mandiri sesuai keinginan konsumen. Vending Machine adalah mesin otomatis yang dapat mengeluarkan berbagai produk seperti makanan ringan, minuman, koran, tiket dll kepada konsumen ketika memasukan uang tunai atau uang elektronik[5].

Teknologi yang digunakan saat ini salah satunya dikembangkan menggunakan konsep teori bahasa dan automata. Finite State Automata (FSA) merupakan mesin abstrak dari bahasa dan teori automata. Teori ini sangat berguna dalam pengembangan teknologi baik perangkat lunak maupun perangkat keras [6]. Finite automata (FA) meliputi state dan transisi yang dapat menerima input dan menghasilkan ouput. FA memiliki himpunan state dan aturan untuk bergerak dari state satu ke state lain tergantung input simbol yang diberikan. Dengan abjad sebagai input yang diijinkan, FA memiliki state awal dan state akhir yang diterima [7]. FSA terdiri dari Deterministic Finite State Automata (DFA) yang hanya menerima satu arah transisi state dan Nondeterministic Finite State Automata (NFA) yang dapat menerima lebih dari satu arah transisi state [8]. NFA pada penelitian ini menggunakan model Mealy Machine. Mealy Machine adalah Finite State Automata dengan input dan output. Eksekusi mealy machine dimulai dari state awal dan dengan mengeksekusi input dan mengubah state. Keluaran yang dihasilkan berdasarkan state saat itu dan bagian masukan atau input [9]. Dalam hal ini, diagram state dari mealy machine memiliki sinyal masukan dan sinyal keluaran untuk tiap transisi.

Penelitian ini bertujuan untuk menerapkan konsep FSA pada desain vending machine angkringan sehingga diharapkan dapat meningkatkan dengan keunggulan berupa otomatisasi, praktis dengan tingkat kebersihan yang lebih baik.

Pada penelitian sebelumnya telah dibahas mengenai vending machine (VM) diantaranya vending machine kopi menggunakan konsep FSA yang dapat 
menerima input uang tunai dan menghasilkan tujuh output varian kopi [10]. Kemudian vending machine dalam melakukan transaksi pengembalian buku di perpustakaan menggunakan konsep FSA dengan fitur pembayaran denda [11]. Selanjutnya terdapat penelitian yang membandingkan sistem simulasi vending machine menggunakan uang tunai dan uang elektronik [12].

Pada penelitian ini akan dibahas mengenai desain vending machine angkringan yang dapat menerima pembayaran berupa uang tunai dan uang elektronik menggunakan konsep FSA. Jenis FSA yang digunakan adalah NFA. Penggunaan NFA ini dipilih karena NFA dapat menerima lebih dari satu arah transisi sehingga dapat mengakomodir varian menu pada VM angkringan. Desain VM angkringan yang dibuat memiliki input berupa pemilihan menu makanan dan minuman beserta kombinasinya dan cara pembayaran berupa uang tunai Rp. 5.000 dan uang elektronik. Pertama kali konsumen melakukan pemilihan menu makanan atau minuman dan cara pembayaran, selanjutnya apabila memilih metode uang tunai dan memasukan uang pecahan Rp 5.000 sampai dengan saldo sesuai harga produk yang dipilih maka mesin akan mengeluarkan produk sesuai pilihan konsumen. Konsumen juga dapat memilih metode pembayaran uang elektronik kemudian melakukan tapping uang elektronik, apabila saldo mencukupi maka mesin akan mengeluarkan produk sesuai pilihan konsumen. Pada bagian selanjutnya akan dibahas metode penelitian, hasil pembahasan dan kesimpulan dari penelitian ini.

\section{Metode Penelitian}

Pada penelitian ini akan digunakan metode penelitian dengan tahapan yang meliputi penerapan konsep FSA VM Angkringan, pengujian FSA VM Angkringan kemudian membuat desain VM Angkringan sebagaimana tampak pada gambar 1 .

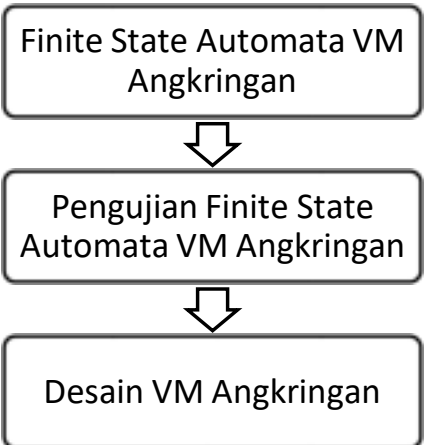

\section{Gambar 1. Tahapan Penelitian}

\section{a. Finite State Automata Vending \\ Machine Angkringan}

Metode Penelitian pada tahap ini akan dilakukan penggambaran cara kerja VM yang meliputi state, event dan action. Konsep FSA yang digunakan adalah NFA dengan model Mealy Machine. NFA merupakan salah satu mesin pada Teori 
Bahasa dan Automata, dipilih karena mudah untuk diaplikasikan dan sesuai dengan logika manusia. Pada NFA, dimungkinkan untuk satu simbol menimbulkan transisi ke lebih dari satu kondisi dan memberikan beberapa kemungkinan gerakan sehingga keluarannya tidak dapat dipastikan [13]. Perancangan diagram state memiliki tahapan yang dimulai dari indentifikasi input, output dan state, perancangan diagram state, menyajikan fungsi transisi dalam tabel dan pembuktian input string yang dapat diterima mesin.

\section{b. Pengujian Finite State Automata VM Angkringan}

Setelah melakukan perancangan diagram state, kemudian dilakukan pengujian terhadap diagram FSA. Pengujian dilakukan untuk menguji apakah formula yang dihasilkan telah memenuhi kondisi dari FSA atau tidak memenuhi. Pada proses pengujian ini akan dimasukan beberapa string huruf kedalam formula apakah bisa diterima mesin atau ditolak mesin.

\section{c. Desain Vending Machine Angkringan}

Tahap terakhir adalah melakukan perancangan desain interface system vending machine angkringan yang dapat menerima input uang tunai, uang elektronik, pemilihan kombinasi menu makanan dan minuman. Desain antarmuka dibuat simple dan menarik agar dapat dipakai pengguna dengan mudah.

\section{Hasil dan Pembahasan}

Hasil dan pembahasan pada penelitian ini akan memaparkan apa yang dikerjakan dan diuji oleh peneliti sesuai dengan metode penelitian yang sudah dijelaskan pada bagian sebelumnya. Tahapan-tahapan tersebut yaitu membuat diagram FSA berdasarkan identifikasi input, output dan state. Setelah diagram dan fungsi transisi dibuat, kemudian dilanjutkan dengan pengujian FSA menggunakan string input dan tahapan terkahir yaitu membuat desain VM.

\section{a. Finite State Automata VM}

Angkringan

Pada pembahasan kali ini akan menggunakan teknik penggambaran state diagram yang merupakan model perilaku dari sistem. Keluaran produk yang dapat dihasilkan oleh vending machine angkringan dapat dilihat pada Tabel 1.

\section{Tabel 1. Keluaran produk dan harga}

\begin{tabular}{|c|l|l|}
\hline No & Produk & Harga \\
\hline 1 & $\begin{array}{l}\text { Wedang Jahe } \\
\text { Original }\end{array}$ & Rp. 5.000 \\
\hline 2 & Wedang Jahe Manis & Rp. 5.000 \\
\hline 3 & Wedang Jahe Susu & Rp. 10.000 \\
\hline 4 & Kopi Original & Rp. 5.000 \\
\hline
\end{tabular}


Tabel 1. Keluaran produk dan harga (Lanjutan)

\begin{tabular}{|c|l|l|}
\hline No & Produk & Harga \\
\hline 5 & Kopi Manis & Rp. 5.000 \\
\hline 6 & Kopi Susu & Rp. 10.000 \\
\hline 7 & Teh Original & Rp. 5.000 \\
\hline 8 & Teh Manis & Rp. 5.000 \\
\hline 9 & Teh Susu & Rp. 10.000 \\
\hline 10 & $\begin{array}{l}\text { Nasi Kucing sate } \\
\text { usus }\end{array}$ & Rp. 10.000 \\
\hline 11 & $\begin{array}{l}\text { Nasi Kucing sate } \\
\text { telur }\end{array}$ & Rp. 10.000 \\
\hline 12 & $\begin{array}{l}\text { Nasi Kucing } \\
\text { gorengan }\end{array}$ & Rp. 10.000 \\
\hline 13 & Nasi Bakar sate usus & Rp. 15.000 \\
\hline 14 & Nasi Bakar sate telur & Rp. 15.000 \\
\hline 15 & Nasi Bakar gorengan & Rp. 15.000 \\
\hline
\end{tabular}

Pada Tabel 1 mengidentifikasikan output produk yang bisa dikeluarkan oleh mesin. Terdapat total 15 produk yang merupakan hasil kombinasi antara menu minuman yaitu wedang jahe, kopi dan teh dengan tanpa tambahan (original), tambahan gula atau tambahan susu dan pada menu makanan yaitu nasi kucing dan nasi bakar dengan tambahan satu usus, sate telur atau gorengan. Rentang harga yang digunakan adalah Rp. 5000, Rp, 10.000 dan Rp. 15.000 sesuai input pilihan makanan dan tambahanya serta minuman dan tambahanya yang dapat dibayar menggunakan input uang tunai atau uang elektronik melalui tapping. Komponen input, output dan state diidentifikasikan pada Tabel 2.

\section{Tabel 2. Identifikasi Input, Output dan} State

\begin{tabular}{|c|l|l|}
\hline Kode & \multicolumn{1}{|c|}{ Uraian } & \multicolumn{1}{|c|}{ Ket. } \\
\hline q0 & Sate Awal & $\begin{array}{c}\text { state } \\
\text { awal }\end{array}$ \\
\hline q1 & Wedang Jahe & state \\
\hline q2 & Kopi & state \\
\hline q3 & The & state \\
\hline q4 & Nasi Kucing & state \\
\hline q5 & Nasi Bakar & state \\
\hline q6 & Original & state \\
\hline q7 & Gula & state \\
\hline q8 & Susu & state \\
\hline q9 & Sate Usus & state \\
\hline q10 & Sate Telur & state \\
\hline q11 & Gorengan & state \\
\hline q12 & Kemasan Minuman & state \\
\hline q13 & Kemasan Makanan & state \\
\hline q14 & Saldo 0 & state \\
\hline q15 & Saldo 5 ribu & state \\
\hline q16 & Saldo 10 ribu & state \\
\hline q17 & Saldo 15 ribu & state \\
\hline q18 & Transaksi Cashless & state \\
\hline q19 & Tap E-Money & state \\
\hline q20 & Produk angkringan keluar & $\begin{array}{l}\text { State } \\
\text { akhir }\end{array}$ \\
\hline 1 & Nilai 1 & Input \\
\hline 2 & Nilai 2 & Input \\
\hline 3 & Nilai 3 & Input \\
\hline 4 & Nilai 4 & Input \\
\hline 5 & Nilai 5 \\
\hline
\end{tabular}

Identifikasi input, output dan state sebagaimana pada Tabel 2 digunakan untuk membuat rancangan diagram 
state dengan konsep NFA mealy machine menggunakan aplikasi JFLAP 7.1 .

Pada gambar 2 dapat dijelaskan konfigurasi FSA Angkringan dengan mealy machine yang memiliki enam tupel, dengan formula sebagai berikut :

$$
\begin{aligned}
\mathrm{M}= & \left\{\mathrm{Q}, \sum, \Delta, \mathrm{q} 0, \delta, \lambda\right\} \\
\mathrm{Q}= & \{\mathrm{q} 0, \mathrm{q} 1, \mathrm{q} 2, \mathrm{q} 3, \mathrm{q} 4, \mathrm{q} 5, \mathrm{q} 6, \mathrm{q} 7, \mathrm{q} 8, \\
& \mathrm{q} 9, \mathrm{q} 10, \mathrm{q} 11, \mathrm{q} 12, \mathrm{q} 13, \mathrm{q} 14, \mathrm{q} 15, \\
& \mathrm{q} 16, \mathrm{q} 17, \mathrm{q} 18, \mathrm{q} 19, \mathrm{q} 20\} \\
\Sigma= & \{1,2,3,4,5\} \\
\Delta= & \{1,0\} \\
\mathrm{q} 0= & \mathrm{q} 0
\end{aligned}
$$

$\delta=$ fungsi transisi input sebagaimana dalam tabel 3

$\lambda=$ fungsi transisi input sebagaimana dalam tabel 4

Diagram state pada gambar 2 menerima input 1,2,3,4,5 dan akan menuju state selanjutnya sesuai input serta menghasilkan output nol dan satu. Apabila menghasilkan output nol maka diagram state tersebut akan lanjut ke state berikutnya sesuai input, dan jika menghasilkan output satu maka mesin sudah menyelesaikan tugasnya dan mengeluarkan produk kemudian akan

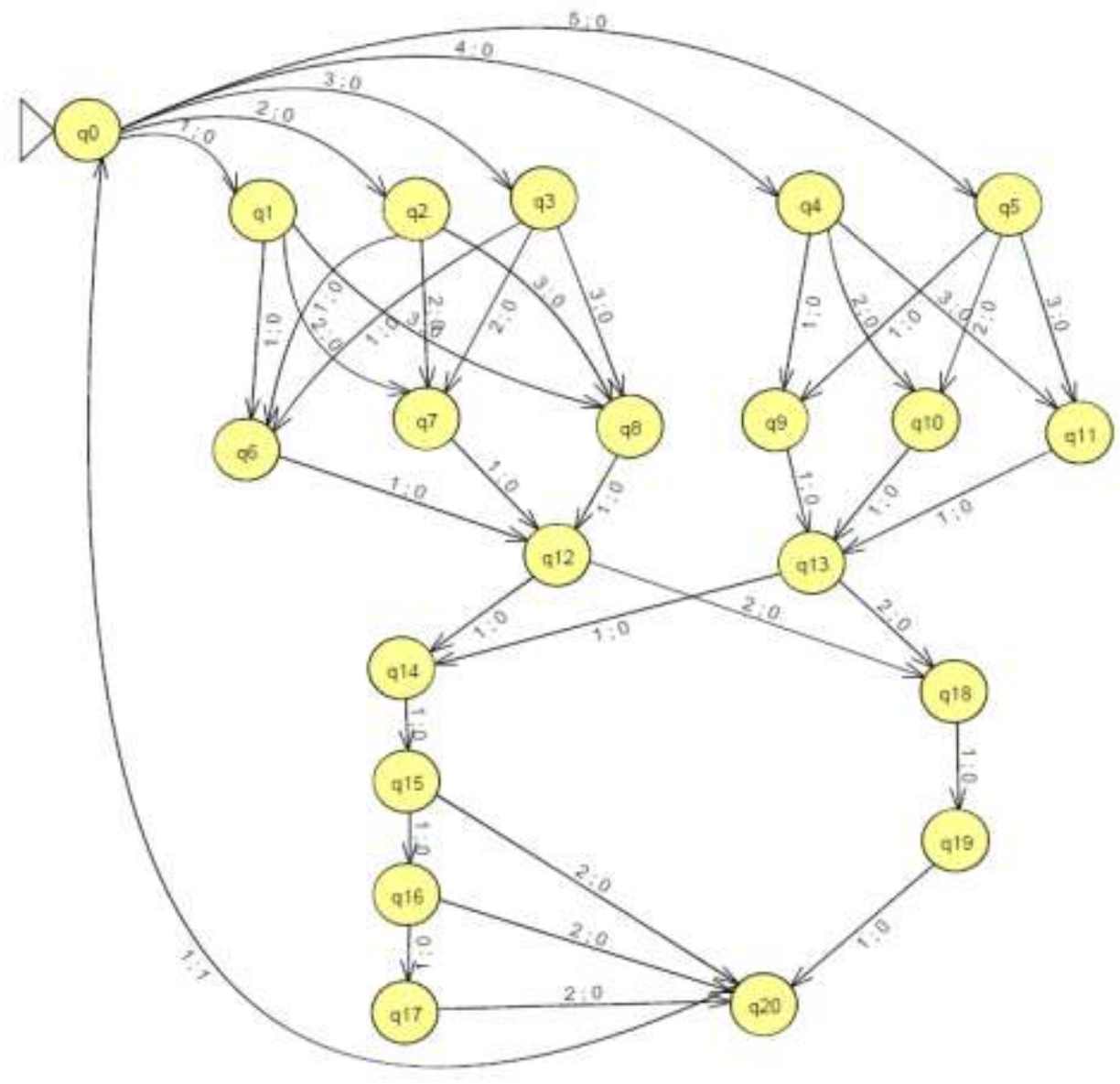

Gambar 2. Rancangan Diagram State 
kembali ke state awal. Diagram state tersebut dapat menerima pembayaran berupa uang tunai pecahan Rp. 5.000 dan uang elektronik. Tabel 3 merupakan pemetaan fungsi transisi input dan Tabel 4 merupakan pemetaan fungsi transisi output

Tabel 3. Fungsi Transisi Input

\begin{tabular}{|c|c|c|c|c|c|}
\hline$\delta$ & $\mathbf{1}$ & 2 & 3 & 4 & 5 \\
\hline q0 & $\mathrm{q} 1$ & $\mathrm{q} 2$ & q3 & $\mathrm{q} 4$ & q5 \\
\hline q1 & q6 & $\mathrm{q} 7$ & q8 & - & - \\
\hline$q 2$ & q6 & q7 & q8 & - & - \\
\hline q3 & q6 & $\mathrm{q} 7$ & q8 & - & - \\
\hline $\mathrm{q} 4$ & q9 & q10 & q11 & - & - \\
\hline q5 & q9 & q10 & q11 & - & - \\
\hline q6 & q12 & - & - & - & - \\
\hline q7 & q12 & - & - & - & - \\
\hline q8 & q12 & - & - & - & - \\
\hline$q^{9}$ & q13 & - & - & - & - \\
\hline q10 & q13 & - & - & - & - \\
\hline q11 & q13 & - & - & - & - \\
\hline q12 & q14 & q18 & - & - & - \\
\hline q13 & q14 & q18 & - & - & - \\
\hline q14 & q15 & - & - & - & - \\
\hline q15 & q16 & q20 & - & - & - \\
\hline q16 & q17 & q20 & - & - & - \\
\hline q17 & - & q20 & - & - & - \\
\hline q18 & q19 & - & - & - & - \\
\hline q19 & q20 & - & - & - & - \\
\hline q20 & $\mathrm{q} 0$ & - & - & - & - \\
\hline
\end{tabular}

Tabel 4. Fungsi Transisi Output

\begin{tabular}{cccccc}
\hline $\boldsymbol{\Lambda}$ & $\mathbf{1}$ & $\mathbf{2}$ & $\mathbf{3}$ & $\mathbf{4}$ & $\mathbf{5}$ \\
\hline $\mathbf{q 0}$ & 0 & 0 & 0 & 0 & 0 \\
\hline $\mathbf{q 1}$ & 0 & 0 & 0 & 0 & 0 \\
\hline $\mathbf{q 2}$ & 0 & 0 & 0 & 0 & 0 \\
\hline $\mathbf{q 3}$ & 0 & 0 & 0 & 0 & 0 \\
\hline $\mathbf{q 4}$ & 0 & 0 & 0 & 0 & 0 \\
\hline $\mathbf{q 5}$ & 0 & 0 & 0 & 0 & 0 \\
\hline $\mathbf{q 6}$ & 0 & - & - & - & - \\
\hline $\mathbf{q 7}$ & 0 & - & - & - & - \\
\hline
\end{tabular}

\begin{tabular}{cccccc}
\hline $\mathbf{q 8}$ & 0 & - & - & - & - \\
\hline $\mathbf{q 9}$ & 0 & - & - & - & - \\
\hline $\mathbf{q 1 0}$ & 0 & - & - & - & - \\
\hline $\mathbf{q 1 1}$ & 0 & - & - & - & - \\
\hline $\mathbf{q 1 2}$ & 0 & 0 & - & - & - \\
\hline $\mathbf{q 1 3}$ & 0 & 0 & - & - & - \\
\hline $\mathbf{q 1 4}$ & 0 & - & - & - & - \\
\hline $\mathbf{q 1 5}$ & 0 & 0 & - & - & - \\
\hline $\mathbf{q 1 6}$ & 0 & 0 & - & - & - \\
\hline $\mathbf{q 1 7}$ & - & 0 & - & - & - \\
\hline $\mathbf{q 1 8}$ & 0 & - & - & - & - \\
\hline $\mathbf{q 1 9}$ & 0 & - & - & - & - \\
\hline $\mathbf{q 2 0}$ & 1 & - & - & - & - \\
\hline
\end{tabular}

b. Pengujian Finite State Automata VM Angkringan

Pengujian FSA yang dilakukan bertujuan untuk mengetahui apakah formula yang dihasilkan telah memenuhi kondisi dari FSA, jika tidak memenuhi maka terdapat kesalahan pada rancangan FSA sebelumnya. Cara yang dilakukan dalam pengujian input string pada diagram FSA menggunakan aplikasi JFLAP 7.1 [14] yaitu dengan mencoba beberapa input misalkan string angka dalam formula untuk mengetahui fungsi transisi apakah sudah sesuai dan tidak terjadi kesalahan dalam proses pemesanan menu angkringan. Jika berhasil mengeluarkan pesanan dengan string berakhir di state awal maka string tersebut dapat diterima oleh mesin, tetapi jika string tidak berhasil mengeluarkan pesanan dan tidak mencapai state awal maka string tersebut tidak diterima oleh mesin. 
Pengujian dilakukan dengan mencoba input string berupa "13111121", "4213111" dan "5312111”. Gambar 3 menunjukan hasil pengujian FSA menggunakan aplikasi JFLAP 7.1. Pengujian pertama menggunakan input string berupa "13111121", pengguna memilih wedang jahe, memillih tambahan susu, memilih kemasan minuman,memilih pembayaran tunai, memasukan uang $\mathrm{Rp}$ 5.000, Rp 5.000, melakukan konfirmasi. Fungsi transisinya adalah sebagai berikut :

$$
\begin{aligned}
& (q 0,13111121) \mid-(q 1, \quad 3111121) \\
& \vdash(\mathrm{q} 8,111121) \\
& \vdash(\mathrm{q} 12,11121) \\
& \text { — (q14, 1121) } \\
& \text { - (q15, 121) } \\
& \vdash(\mathrm{q} 16,21)
\end{aligned}
$$

- (q20,1) menghasilkan output 1

- (q0) kembali ke state awal (strings diterima)

Pengujian pertama menjelaskan pengguna yang membeli wedang jahe susu maka state awal q0 kemudian memilih wedang jahe maka akan menuju state q1. Setelah pengguna memilih wedang jahe dan state ada di q1 selanjutnya memilih tambahan susu kemudian akan menuju state q8. Mesin akan menyiapkan kemasan minuman dan akan diminta memilih cara pembayaran yaitu uang tunai atau uang elektronik. Uang tunai yang diterima adalah Rp 5.000, apabila pengguna mamasukan uang tunai Rp 5.000 (1) maka

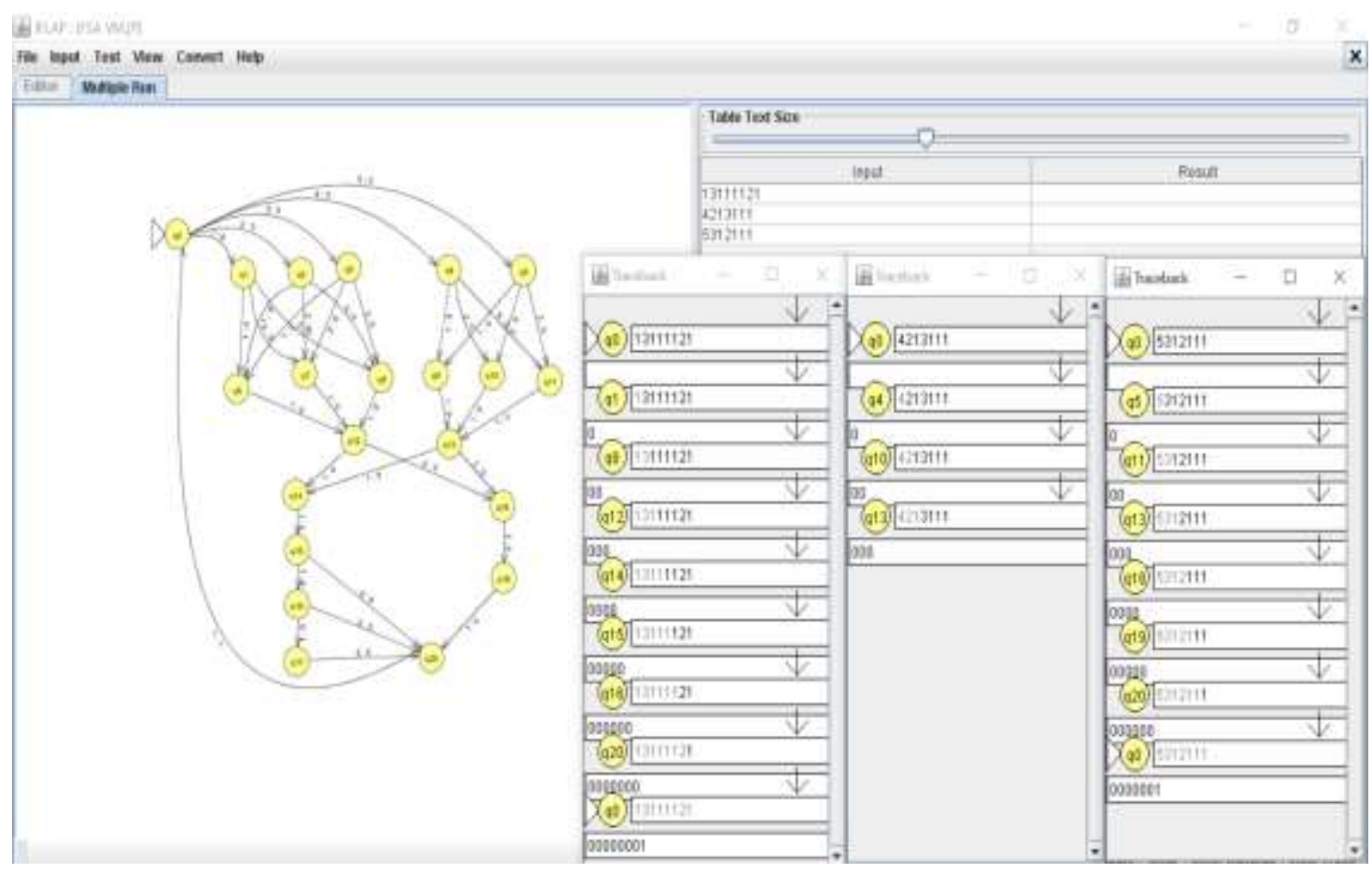

Gambar 3. Hasil Pengujian FSA menggunakan Aplikasi JFLAP 7.1 
saldo menjadi Rp 5.000 menuju state q15. Jika memasukan uang Rp 5.000 lagi maka saldo menjadi Rp 10.000 dan menuju state q16. Setelah saldo sesuai dengan harga produk maka selanjutnya pengguna melakukan konfirmasi (1) menuju state q20 dan produk akan dikeluarkan mesin sesuai dengan pesanan kemudian kembali ke state awal

Pengujian kedua menggunakan input string berupa "4213111", pengguna memilih nasi kucing, memillih tambahan sate telur, memilih kemasan makanan, kemudian memilih input 3 yang tidak terdapat dalam daftar transisi sehingga string berhenti di state q13. Fungsi transisinya adalah sebagai berikut :

$$
\begin{aligned}
(\mathrm{q} 0,4213111) & \longmapsto \\
- & (\mathrm{q} 4,213111) \\
& (\mathrm{q} 10,13111) \\
& (\mathrm{q} 13,3111) \\
& - \text { tidak menghasilkan } \\
& \text { output } 1 \quad \text { (strings } \\
& \text { ditolak) }
\end{aligned}
$$

Pengujian ketiga menggunakan input string berupa "5312111", yaitu pengguna yang membeli nasi bakar dengan tambahan menu gorengan. Pertama pengguna akan memilih nasi bakar dengan keluaran nol menuju state q5, memillih tambahan gorengan dengan keluaran nol menuju state 11, mesin menyiapkan kemasan makanan menuju state 13 , memilih pembayaran uang elektronik dengan keluaran nol menujuu state 18, melakukan tapping, melakukan konfirmasi dengan keluaran satu dan menghasilkan produk nasi bakar ditambah gorengan. Fungsi transisinya adalah sebagai berikut :

$$
\begin{aligned}
& \text { (q0, 5312111) - (q5, 312111) } \\
& \text { - (q11, 12111) } \\
& \text { - (q13, 2111) } \\
& \text { — (q18, 111) } \\
& \text { - (q19, 11) } \\
& \text { - (q20, 1) menghasilkan } \\
& \text { output } 1 \\
& \text { - (q0) kembali ke state } \\
& \text { awal (strings diterima) }
\end{aligned}
$$

\section{c. Desain Vending Machine \\ Angkringan}

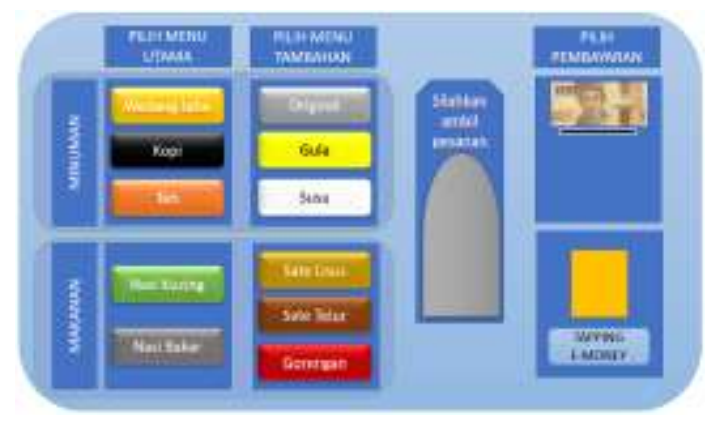

\section{Gambar 4. Desain Antarmuka VM Angkringan}

Tampilan antar muka VM Angkringan seperti yang pada gambar 4 dibuat sederhana dan warna-warni agar menarik konsumen dan memudahkan dalam pemilihan menu baik menu makanan atau menu minuman. Cara kerja VM angkringan tersebut adalah pengguna akan memilih menu utama baik makanan atau minuman 
kemudian diminta untuk untuk memilih menu tambahanya. Setelah pengguna melakukan pemilihan produk kemudian mesin akan menyiapkan kemasan baik minuman atau makanan. Pada tampilan antarmuka VM angkringan terdapat pilihan metode pembayaran, pengguna kemudian melakukan pemilihan metode pembayaran. Jika memilih menggunakan uang tunai maka gambar uang Rp 5.000 akan menyala kemudian memasukan uang tunai pecahan Rp 5.000. Gambar uang tersebut akan terus menyala sampai dengan jumlah uang yang dimasukan sama dengan harga produk, apabila sudah sesuai maka VM angkringan akan mengeluarkan produk sesuai yang dipilih pengguna. Sedangkan apabila pengguna memilih metode uang elektronik maka indikator tapping e-money akan menyala. Setelah pengguna melakukan tapping e-money dan mesin berhasil melakukan penarikan saldo sesuai harga produk, maka VM angkringan akan mengeluarkan produk sesuai dengan pilihan pengguna.

Pada penelitian sebelumnya telah dihasilkan penerapan FSA pada vending machine susu kambing etawa yang dapat menerima pembayaran tunai dan non tunai dengan tujuh pilihan produk [15]. Kemudian penerapan FSA pada vending machine rujak buah dengan kombinasi produk rujak buah yang lebih banyak tetapi hanya dapat menerima pembayaran tunai [7]. Sedangkan pada penelitian ini dihasilkan desain vending machine angkringan dengan konsep FSA yang dapat menghasilkan lebih banyak pilihan produk.

\section{SimpUlan}

Berdasarkan perancangan vending machine $\mathrm{VM}$ angkringan yang menggunakan konsep FSA dengan berbagai variasi menu makanan dan minuman serta metode pembayaran, maka dapat disimpulkan bahwa penggunaan NFA pada desain VM angkringan tersebut dapat diterapkan. Desain VM angkringan tersebut sudah divalidasi dengan pengujian diagram FSA, dimana VM angkringan dapat menerima input string dan dengan kondisi tertentu dapat menghasilkan output. VM angkringan dapat dimanfaatkan untuk meningkatkan segmen pasar angkringan karena dapat diletakan di tempat-tempat strategis dan menjangkau lebih banyak konsumen. Berbagai pilihan produk dan variasinya dengan total 15 keluaran produk dapat memenuhi kebutuhan konsumen karena hampir sama dengan menu yang ada di warung angkringan. Penggunaan metode pembayaran uang tunai dan uang elektronik juga menjadi nilai tambah VM angkringan karena memudahkan konsumen untuk melakukan pembayaran sesuai keinginan. 
Penelitian ini memberikan implikasi secara teoritis dan praktis. Implikasi teoritis yaitu FSA yang merupakan mesin abstrak dari bahasa dan teori automata dapat diterapkan dalam membuat desain VM angkringan. Sedangkan implikasi praktis yaitu hasil penelitian ini dapat digunakan oleh produsen VM dalam mengembangkan dan membuat VM angkringan sehingga dapat berguna untuk usaha angkringan dalam meningkatkan nilai tambah dan memperluas pangsa pasar.

Saran untuk penelitian selanjutnya adalah melakukan penambahan menu makanan dan minuman misalnya kepala ayam, sate keong, kopi joss dan sabagainya yang menurapakan menu khas angkringan agar dapat memberikan pilihan lebih banyak kepada pembeli, serta penambahan cara pembayaran menggunakan dompet digital misalnya OVO, Go-pay, Dana, LinkAja dan sebagainya.

\section{Daftar Pustaka}

[1] H. Dewantara, "Mekanisme Bertahan Pedagang Angkringan di Era Disrupsi," J. Pendidik. Sosiol. dan Antropol., vol. 3, no. 1, 2019.

[2] I. W. Redi Aryanta, "Manfaat Jahe Untuk Kesehatan," Widya Kesehat., vol. 1, no. 2, pp. 39-43, 2019, doi: 10.32795/widyakesehatan.v1i2.463. [3] . K., "Strategi Adaptasi Pedagang
Angkringan

dalam

Mempertahankan Eksistensi Hidup Studi di Kawasan Jl. K.H. Ali Maksum Krapyak Yogyakarta," JESI (Jurnal Ekon. Syariah Indones., vol. 5, no. 2, p. 171, 2016, doi: $\quad 10.21927 /$ jesi.2015.5(2).171190.

[4] M. Handayani, SB \& Taufik, "Analisa Keputusan Konsumen Warung Angkringan ( Studi Kasus Pada Warga Kos di Kota Semarang )," J. Ekon. Manaj. dan Akunt., vol. 24, no. 43, p. 9, 2017.

[5] A. K. Kumar, "Design of Vending Machine Using Verilog Hdl," JETIR, vol. 5, no. 7, pp. 1346-1350, 2018.

[6] M. M. Sulaiman, R. Andrianto, and M. A. Yulianto, "Mobile Learning Application for Language and Automata Theory using Androidbased," J. Online Inform., vol. 5, no. 2, p. 176, 2020, doi: 10.15575/join.v5i2.630.

[7] R. A. Nugraha, A. Mulyani, and W. Gata, "Desain Vending Machine Rujak Buah Dengan Finite State Automata," IJCIT (Indonesian J. Comput. Inf. Technol., vol. 5, no. September, pp. 198-207, 2020.

[8] J. Setia and B. No, "Pemodelan Vending Machine dengan Metode 
FSA ( Finite State Automata ), J.

Comput. Inf. Technol., vol. 2, no. 2, pp. 66-69, 2019.

[9] M. Tappler, B. K. Aichernig, and R. Bloem, "Model-Based Testing IoT Communication via Active Automata Learning," Proc. - 10th IEEE Int. Conf. Softw. Testing, Verif. Validation, ICST 2017, pp. 276-287, 2017, doi: 10.1109/ICST.2017.32.

[10] B. Richardson, K. Hendy, V. Andiyani, and W. Philips, "Penerapan Konsep NonDeterministic Finite Automata (NFA) pada Aplikasi Simulasi Mesin Kopi Vending," J. Inform. Univ. Pamulang, vol. 4, no. 1, p. 1, 2019 , doi: 10.32493/informatika.v4i1.2062.

[11] R. Riduan Achmad, F. F. Septiana, N. Syamsi, B. S. Prakoso, and H. B. Novitasari, "Penerapan Finite State Automata pada Vending Machine dalam Melakukan Transaksi Pengembalian Buku di Perpustakaan," Metik J., vol. 5, no. 1, pp. 63-70, 2021, doi: 10.47002/metik.v5i1.219.

[12] D. Sujana1 and W. S. , Qiswah Mardzotillah2, Adim Nuraidin3, Muhammad Abdul Rosip4, "Komparasi Analisa Sistem
Simulasi Vending Machine Autimatic Cash Money Dan EMoney Di Universitas Islam Syekh Yusuf Tangerang," Jutis, vol. 7, no. 1, p. 11, 2021.

[13] N. D. Wirasbawa, L. Benedict, B. G. Santoso, M. F. Farhan, and A. Kusnadi, "Penerapan Konsep NonDeterministic Finite Automata Untuk Pembuatan Sereal Menggunakan Mesin Jual Otomatis Dengan Dua Sistem Pembayaran," Simp. Nas. Ilm., no. November, pp. 440-448, 2021, doi: 10.30998/simponi.v0i0.375.

[14] A. Sudrajat, W. Gata, E. H. Hermaliani, and L. Kurniawati, "Implementasi Finite State Automata Pada Aplikasi Simulasi Vending Machine Frozen Food," J. Sains Komput. dan Teknol. Inf., vol. 4, no. 1, pp. 66-71, 2021.

[15] K. Handayani, D. Ismunandar, S. A. Putri, and W. Gata, "Penerapan Finite State Automata Pada Vending Machine Susu Kambing Etawa," Matics, vol. 12, no. 2, pp. 87-92, 2021 , doi: 10.18860/mat.v12i2.9270. 